\title{
An Analysis of Images of Contention and Violence in Dagara and Akan Proverbial Expressions
}

\author{
Martin Kyiileyang (Corresponding author) \\ Department of English Education, University of Education, Winneba, Winneba, Central Region, Ghana, West Africa \\ E-mail: mkyiileyang@gmail.com \\ Michelle Ama Debrah \\ Department of English Education, University of Education, Winneba, Winneba, Central Region, Ghana, West Africa \\ E-mail:amadebrah@gmail.com \\ Rebecca Williams \\ Department of English Education, University of Education, Winneba, Winneba, Central Region. Ghana, West Africa \\ E-mail:wilsbeck41.rw@gmail.com
}

Doi:10.7575/aiac.alls.v.8n.2p.222

URL: http://dx.doi.org/10.7575/aiac.alls.v.8n.2p.222
Received: $18 / 03 / 2017$

Accepted: 14/04/2017

The research was financed by authorities of the University of Education, Winneba through our monthly salaries and the Book and Research Allowances.

\begin{abstract}
Proverbial expressions have typical linguistic and figurative features. These are normally captivating to the listener. The expressive culture of the Dagara and Akan societies is embellished by these proverbial expressions. Most African proverbs, express various images depicting both pleasant and unpleasant situations in life. Unpleasant language normally depicts several terrifying images particularly when threats, insults and other forms of abuse are traded vehemently. Dagara and Akan proverbs are no exceptions to this phenomenon. This paper seeks to examine images of contention and violence depicted in Akan and Dagara proverbial expressions. To achieve this, a variety of proverbs from Akan and Dagara were analysed for their meanings using Yankah's and Honeck's Theories. The result revealed that structurally, as with many proverbs, the Akan and Dagara proverbial expressions are pithy and terse. The most dominant images of contention and violence in these expressions expose negative values and perceptions about the people who speak these languages.
\end{abstract}

Keywords: Akan, Dagara, Proverb, Imagery, Contention, Violence

\section{Introduction}

\subsection{African Oral Traditions}

The scope of African oral traditions is wide. It covers, among others, proverbs, riddles, folktales, folk music, dirges, drum language and lyrical poems. Most of these oral art forms are used in one form or another in both the traditional and the modern urbanised African societies. They are often used in various contexts such as farming, festivals, funerals, marriage ceremonies, religious rites, and entertainment. The natural place of African folklore and oral traditions, in general, is the people's verbal and performing arts, their oral literature, material culture as well as their beliefs, customs and socio-political institutions.

Folk literature to a large extent is an important aspect of folklore and therefore, forms a vital part of the cultural heritage of the ordinary people (Egonu, 2010). Again, it encapsulates certain values and ideals, customs and beliefs that are greatly cherished by the community. These values are normally inculcated into the youth as essential ingredients for a proper social organisation. By this organisation, immorality is condemned and the virtues of kindness and honesty are cherished. Every form of evil is censored in order to create a peaceful and healthy social balance.

Even though African folk literature is basically oral in nature, it also contains the same literary features of form, expression, mode, context, meaning and themes as found in written literature. Folk literature also expresses and exposes community integration, collective wisdom, cosmic relationship, natural justice and shared entertainment which are all part and parcel of traditional African society. It is essential to recall that these features of African folk literature have been highlighted in an unpublished paper entitled "Oral Literature and Education among the Igbo of Nigeria" (Egonu, 2010).

In Ghana, most ethnic groups, if not all, have their own oral traditions. Proverbs are an important part of their oral traditions. It is believed that a good orator is one whose speech is interspersed with proverbs. Asante (2002, p.2) quotes 
an eloquent sub-chief of Mamfe-Akwapem as saying "Bebu ye Twi kasa mu nkyene to" which translates as "proverbs serve as salt, seasoning the speeches of the Twi-speaking people." Proverbs as a means of communication, therefore, reflect all aspects of human endeavour and social discourse in Ghanaian society. Contention and violence emanate out of social discourse as an indication of discomfort which in turn promote peace and harmony. It is against this background that this paper sets the task of analysing Akan and Dagara proverbial expressions which depict images of contention and violence.

\subsection{The Role of Proverbs in Africa}

In black Africa, the ordinary people use proverbs frequently in their daily life. The cultural heritage of the people, their traditions, history, wisdom and ethics are all embedded with proverbs. They are reliable means of transmitting culture from one generation to another. If this were not possible, norms, values and beliefs would have been forgotten outright. Proverbs prepare young generations for great tasks and challenges in their various societies. These young people learn good manners and cultivate respect for elders. Therefore, proverbs help in broadening the educational, social, psychological and economic development of children and young people in general in their various traditional societies. Proverbs are a peculiar means of communication widely used the world over. "Their comparison provides insight into the effects of cultural traditions. It is a fact that communication is more effective within and beyond one's ethnic group through the effective use of proverbs (Pachocinski, 1996 cited in Kyiileyang, 2009, p. 34). In some societies, proverbs are peculiar and extraordinary devices of communication which are kept secret by elders because they are regarded as the jewels of wisdom. In fact, some of them are quite difficult to understand. Proverbs are used in various contexts to reinforce language making it carry more weight and give more meaning. Proverbs can also be used to draw parallels between two or more situations in society. Proverbs can also refer to the philosophy of life, some basic traditional values and actually contain non-written laws of the land. They are approved and sanctioned by the community as a whole. Proverbs also contain the ancient wisdom of black African people. Their usage covers a wide range including "social and cultural activities ranging from polite advice to sympathetic expression of hope in providence" (Pachocinski, 1996, p. 2 cited in Kyiileyang, p. 35). In situations of disputes and legal matters, the one who is gifted in proverbs is always in a better position to defend himself or herself. Black African people are generally a reliable storehouse for oral literature, tradition, poetry, proverbs and folklore (Pachocinski, 1996, p. 3).

\subsection{Towards a Comprehensive Definition of the Term 'Proverb'}

Many experts have given several definitions of the term 'proverb'. Definitions from both Africans and non-Africans have been given consideration in this study. About two thousand years ago, Aristotle referred to proverbs as "fragments of ancient wisdom preserved amid wreck and ruin for their brevity and aptness" (Dalfovo, 1984, p. 2). Ten scholars of earlier times gave a variety of definitions of the term 'proverb' as it was understood in their contemporary societies (Hulme, 1968). It is good to begin with Samuel Johnson who defines a proverb in his dictionary as "a short sentence frequently repeated by the people, a saw; an adage" (Hulme, 1968, pp. 3-4.) Synesius affirms that "a proverb is a remnant of the ancient philosophy preserved amid much destruction on account of brevity and fitness for use" (Hulme, 1968 , p. 5). It is significant to point out that the word proverb is Greek in origin and actually means literally, a wayside saying. Agricola defines proverbs as "short sentences into which as in rules, the ancients have compressed in life" (Hulme, 1968, p. 6). Cervantes gives a pithier definition as follows: "short sentences drawn from long experience" (Hulme,1968, p. 6). Russell declares that a proverb is "the wisdom of many and the wit of one" (Hulme, 1968, p. 6). However, Roger Bacon defines a proverb as "the genius, wit and spirit of a nation" (Hulme, 1968. p. 6). On the other hand, Chamber regards proverbs as "pithy, practical popular sayings expressive of certain more or less general convictions." (Hulme, 1968, p. 6) Additionally, Annandale points out that "a proverb is a short and pithy sentence forming a popular saying, and expressing some result of the experience of life in keen, quaint, and lively fashion" (Hulme, 1968, p. 6). Other definitions worth considering on the term 'proverb' include the following. Worcester defines a proverb as "a common or pithy expression which embodies some moral precept or admitted truth" (Hulme, 1968, p. 7). Apart from these definitions, Hazlitt has a typically literary definition of the term: it is "an expression or combination of words conveying a truth to the mind by a figure, periphrasis, antithesis or hyperbole" (Hulme, 1968, p.7).

Gabor Nagy O. also posits that a proverb is a "popular set phrase having no authors, known mostly in different languages; expressing in one sentence a principle, advice, a genuine or assumed truth in a general, concise form, its basic idea being of general validity, at least its user considers as such (O.Gabor,1979, p. 645).

Another theory views proverbs as stereotype linguistic entities.

A proverb is a stereotype linguistic entity expressing a fixed idea. On the linguistic level it is an artistic picture, on the level of ideas, a judgement. As a work of art of folklore, it belongs to the secondary semiotic systems. It is a communication system with a double code, a carrier of information at the level of language, but at the same time, the information carries content too, becoming an instrument of poetic expression (Voo, 1989, p.19).

The Spanish describe the proverb as "a short sentence based on long experience". The Dutch refer it as "the daughter of daily experience" while the Germans posit that proverbs can be compared to butterflies as "some are caught and some fly away". Also, the Arabs claim that "a proverb is to speech what salt is to food". Generally speaking, proverbs are 
popular sayings that express commonly held truths, with their chief ingredients, according to James Howell, being "sense, shortness, and salt". They are "the wit of one and the wisdom of many". Sir Francis Bacon had pointed out that "the genius, wit, and spirit of a nation are discovered in its proverbs". Some 2,000 years before Bacon's time, Aristotle had gathered his own collection of 'ancient' proverbs, referring to them as "fragments of an elder wisdom" whose "brevity and aptness" had preserved. (Stone, 2006, pp. xii-xiii).

Ibn Ezra describes the proverb as having three main characteristics. These are few words, good sense, and a fine image. The world's leading paremiologist, Wolfgang Mieder, acknowledges the difficulty of providing a comprehensive definition. Nevertheless, he defines the proverb as "a short, generally known sentence of the folk which contains wisdom, truth, morals, and traditional views in a metaphorical, fixed and memorisable form and which is handed down from generation to generation" (Mieder, 2004, p. 3).

Norrick (1985) uses a linguistically crafted matrix and isolates the key features of the proverb as follows: (1) a propositional statement, (2) sayings woven into the fabric of a conversation (3) a traditional and spoken statement (in contrast to aphorisms) which are statement of insight, often paradoxical and thought provoking and epigrams which are typically written, non-traditional, and attributed to a particular author and (4) a fixed form with didactic intent and completeness of thought. Furthermore, a proverb is a generalisation, unlike a curse or blessing that is personal and particular. A proverb may be figurative when it uses metaphors or similes, and literal maxims. Usually, it is poetically enhanced through such techniques as rhyme, alliteration, ellipsis, paronomasia, repetition or parallelism which aid in making it memorable and quotable (Mieder, 2004, p.7). Additionally, Whiting (1932, pp.278, 301-302) describes a proverb an expression which owing its birth to people, testifies its origin in form and phrase. It expressed what is apparently a fundamental truth; (that is, a truism in homely language) often adorned, however, with alliteration and rhyme. It is usually short but needs not be; it is usually true but need not be. Some proverbs have both a literal meaning and a figurative meaning, either of which makes perfect sense, but more often they have but one or two. A proverb must be venerable, it must bear the sign of antiquity, and since such signs may be counterfeited by a clever literary man, it should be attested in different places and different times.

According to Dundes (1975, p. 970), structurally a proverb is often composed of a topic and comment. In fact, he explains that a proverb is "a traditional prepositional statement consisting of at least one descriptive element consisting of a topic and a comment."

If the proverb is metaphorical, its common, non-metaphorical meaning must be deduced. For example, "don't cry over spilt milk" literally means, one should not waste time worrying about things that cannot be undone or changed. This literal meaning then may be employed in a diverse range of situations. So a soccer coach quotes this proverb to encourage her team to move on after a loss.

Bradbury (2002, p. 270) cites Lakoff and Turner who also contend that proverbs can be treated as poems based on examples drawn from Merwin's (1989, p.160) book of poetry. However, Honeck (1997, p.18) defines the term 'proverb' derived from his 'conceptual base' theory as follows: "A proverb can be regarded as a discourse deviant, relatively concrete, present (non-past) tense statement that uses characteristic linguistic markers to arouse cognitive ideals that serve to categorise topics in order to make a pragmatic point about them". By 'discourse deviant' it means a proverb does not follow the usual rules as in the following example: 'Not every oyster contains a pearl'. According to Honeck, the listener first tries with great difficulty to interpret the statement literally. Even if the listener has never heard the saying 'Not every oyster contains a pearl', he or she realises that the statement has no "immediate referent" that is, no oyster can be seen at that moment. Ideally, all oysters would contain pearls like many others. However, the proverb quoted here emphasises the contrast between the ideal and the imperfect reality. Honeck's theory states that proverbs are problems that require solutions rather than poems which require interpretations. He refers to it as the 'conceptual base' theory after the mind in which this problem solving takes place. Unlike Lakoff and Turner who treat proverbs as literary texts, Honeck places speakers in face-to-face situations.

If there is any comprehensive definition of the term 'proverb', then it comes from the one provided by Archer Taylor. In a dictionary of folklore, mythology and legend, Taylor $(1995$, p. 902) he states categorically that a proverb is a "terse statement that is current in tradition or as an epigram says, "The wisdom of many and wit of one." He stresses that ordinarily, a proverb suggests a course of action. Sometimes too, it also passes judgement on something or somebody. Furthermore, he says that a proverb may be merely a statement of fact. He argues that the origin of the term proverb is obscure. Archer Taylor contends that perhaps somebody formulated an idea in words some time ago or drew a lesson from a scene but ultimately it turned out to be an intelligent remark exemplifying a truth until tradition accepted the statement and adapted for a suitable application. Kuusi (1972) proposes that proverbs are characterised by binary oppositions similar to many of the biblical antithetic proverbs.e.g. "For whosoever will save his life shall lose it, but whosoever shall lose his life for my sake and the gospel's, shall save it" (Mk 8:35).

It is equally important to point out that Yankah pays particular attention to the definition of the term proverb. According to him " $\varepsilon$ be may refer to the universally known proverb, but it also embraces moral-embedded extended metaphors, illustrative anecdotes, and parables, when these are used to drive home a moral in an on-going interaction" (Yankah, 1989, p.88). However, in Akan fictional tales, "Anansesem" also becomes " $\varepsilon$ be" when it is used "as an illustrative anecdote in discourse interactions" (Yankah, 1989, p.88). Furthermore, Yankah points out that the wider and extended meaning of the term 'proverb' is not found only in Africa but also outside the African continent. Archer Taylor contends that "the nearest Greek term for the proverb refers to proverb and fable; the Aramaic-Syriac 'mathla' as well as the old English 'gied' have similar denotations" (Taylor, 1931/1962 cited in Yankah, 1989, p.89). Yankah further 
calls for two broad analytical proverb types and these are the "attributive" proverb (which is often shorter and in 'quoted' forms ascribed to authoritative, impersonal or personal sources) and the "non-attributive" proverb (which is longer in form and also refers to fables, parable, story) that is often not preceded by authorship formula. Some proverbs are borne out of some tales as among the Limba of Sierra Leone and people of Russia. Other proverbs too are allusive in nature as among the Ewe where new proverbs are created in discourse. In such situations, these proverbs become "extended metaphors in which morals are embedded" (Anyidoho, 1983 cited in Yankah, 1989, p. 90). Additionally, a whole tale could also be regarded as a proverb. Among the Akan, "Anansesem" is usually performed. However, "when the same tale appears as an illustrative anecdote in a conversational context, it is $\varepsilon b \varepsilon "$ (Yankah, 1989, p. 93). Other ways of understanding proverbs include innuendo, dirges, drum language and visual art. "Even though the Akan proverb is mainly spoken, it may also be drummed, and depicted in visual art. In some situations, proverbs may be expressed through an unusual dress style or demeanour" (Yankah, 1989, p. 98). Nowadays, the fixity of proverbs is controversial. Contrary to past definitions, the form and meaning of the proverb are not fixed. They move together with usage. Proverbs have multiple meanings.

According to Yankah, (1989, p.153), "the proverb does not stay at one place, it flies". Dalfovo emphasises that the diversity of Lugbara culture is reflected in its language. These linguistic differences are recognised in the variants that exist in several Lugbara proverbs. Therefore, the fixity of a Lugbara proverb is found in its main pattern. However, practically, when a proverb is used listeners can easily respond in one of its variants (Dalfovo, 1984, p.10). Thus, Yankah (1989, pp. 28-29) refers to "an analytical dichotomy between the proverb concept and proverb in context." The problem of fixity is even compounded by the contradictory nature of proverbs as some advocate. At the proverb concept level, one deals with cultural truism or social fact which may be confirmed or contradicted. A proverb can cease to be fact-oriented and assume the nature of an opinion, confirming or validating the judgement or opinion the speaker has already formed. Yankah, (1989) further contends that there are certain attributes of the proverb which make it an effective device of persuasion. Three factors account for these. These include the appeal to cultural truth, literary value and impersonal form. The cultural truth in proverbs is often attributed to ancestral wisdom. The literary value of the proverb makes it more effective.

Muller also explains that proverbs are indeed bits of ancient wisdom that bear significant features of the early days of mankind. However, their charm is not simply to be found in their being artifacts of ancient times or in their brevity and wit but in the way they draw upon and reflect the common human experiences that are shared across time and space. One of the most distinctive and intriguing features about the proverb is its freshness, applicability and continued relevance to every age, even up to the present. For example, in the book of Proverbs, King Solomon compares a gold ring in a pig's snout to a beautiful woman who lacks discretion, in order to give caution to people of his time and equally to our present generation.

Elwell-Sutton (1954) makes a similar observation when he indicates that in the East and West alike, people "bury the hatchet", they "lay the axe to the root," they ask "who will bell the cat," they observe that "dog does not eat dog," and they laugh at "the pot for calling the kettle black". Even a cursory glance at the collections of proverbs, such as those by Burton Stevenson and S.G. Champion, or by Rosalind Fergusson and Wolfgang Mieder, gives evidence of shared human concepts and experiences, if not borrowed turns of phrase. All these similarities are certainly remarkable (Elwell-Sutton 1954, Stevenson 1948, Champion 1938, Fergusson 1983, Mieder 1986 all cited in Stone, 2006, p. xiii).

In fact, there is no overarching theory of proverbs. Instead, different views have emerged: seven distinguishable views regarding the proverb exist. These are personal, formal, religious, literary, practical, cultural and cognitive. The personal view states that proverbs can be treated from a subjective viewpoint based purely on personal experience and understanding. A formal perspective is a scientific approach that primarily uses the methods and concepts of linguistics, logic and semiotics to define, classify and otherwise analyse proverbs. However, the religious teaching and wisdom are examined in texts such as Bibles. In another way, proverbs in prose and poetry are analysed in terms of their literary value and what they tell us about the writer and their times. The practical view says that there are many uses of proverbs for intelligence testing, advertising, psychotherapy and other areas. However, the cultural and cognitive perspectives are also equally scientific approaches to the understanding of the term 'proverb' Whilst the cultural treats it as a multifunction form of folk literature that arises from and is embedded in a socio-linguistic context the cognitive approach is based on cognitive science that attempts to explain how individuals use and understand proverbs (Honeck, 1997, pp.1-6).

Each of these views has something unique and positive to contribute to our knowledge of the proverb but they do not contribute equally to our understanding of proverb cognitive. The personal, religious, literary and practical views project little scientific goals. The formal, cultural and cognitive views do but differ in goals, assumptions, method and theoretical products. There have been positive developments in the mixture of all the scholarly views except for the cognitive view which has remained relatively isolated from the others. On the larger scale, cognitive scientific interest and research on the proverb have lagged behind that of the non-cognitive scientific views.

The value and importance of ancient and modern proverbs from peoples around the world lie in what they can learn about customs and cultures different from theirs. Proverbs can equally teach people about their own character. ElwellSutton emphasises that a study of a people's proverbs and the folk-lore embedded in them can also give an idea of outside influences to which they have been subjected in the past. 


\section{Theoretical Framework}

Yankah (1989) posits that the proper use of proverbs is situational context. He points out that the indigenous theory of proverb authorship revolves around the notion of proverb authorship, the art of keeping proverbs in custody and the skills of creativity by professional custodians engaged in public performances. Thus, the proverb is performed within a complex network of discourse interaction. Discourse is not limited to audible speech but any situation in which communication is anticipated. Honeck (1997) affirms that cultural contexts enrich the study of proverbs but argues nevertheless that for theoretical purposes, proverbs can be abstracted from the cultural specifics because the mental structures and processes of homo sapiens are explainable on the basis of the same theoretical principles.

\section{Background of the Dagara and Akan People}

Historically, the Dagara originated from the Mole-Dagbani people of northern Ghana. The traditional area of the Dagara is Nandom in the newly created Nandom District of the Upper West Region of northern Ghana. The Dagara are a section of the 'Dagaaba'. The term Dagaaba is used to describe several speakers of varieties of Dagaare spoken mostly in the Upper West Region. The main varieties spoken are 'Waali'; spoken in Wa and its surrounding areas, 'Manlaali' spoken in Nadowli and its surroundings, 'Losaali' spoken in Lawra, 'Jirbaali' spoken in Jirapa and its surrounding areas such as Bo, Kaani, Tampaala, Nyeni, Tiza and Duori. The rest of the varieties of Dagaare are 'Birifor spoken in Baabile and 'Dagara' spoken in Nandom and its surrounding areas such as Ko, Guo, Hamile, Fielmuo and Piina. The Dagaaba constitute the largest ethnic group - seventy per cent (70\%) - in the Upper West Region. (McCoy, 1988, p. 35, Kyiileyang, 2009, pp.81-84).

There are many aspects of Dagara traditions which are cherished and practised by the Dagara. The main ones include subsistence farming, festivals; the two most significant ones being the 'Bagre' and the 'Kakube' Festivals. Other aspects of Dagara Traditions are funerals, traditional marriage, traditional music as well as traditional religion. Most of these traditions such as 'bagre', marriage arrangements, identification of family farm boundaries by feuding factions and veneration of the dead are quite complex in nature and often attract experts in Dagara tradition. Those who are ignorant avoid being entangled with the nitty-gritty of traditional practices often treated with great care and caution.

The Akan people as we know today, trace their emergence from the Sahel region. It is believed that they are one of the largest, if not the largest ethnic group in West Africa. Numbering approximately 20,000, they are scattered across present-day Ghana and La Côte d'Ivoire. They are classified into various sub-groups. In Ghana, they include the Asante, the Akyem, Fante, Bono, Akwapem, Akwamu, Denkyira, Kwawu and the Ahanta, among others. The Akan are bound by a common language: Akan, spoken in various dialects by the various groups (Yankah, 1989). Akan culture is characterised by art such as the crafting of bronze, gold weights. They are noted for their mythological ananse stories ('anansesem') which depict a popular trickster-character known Ananse. Other aspects of Akan culture include their festivals and related rituals and celebrations, their kente, chieftaincy, rites of passage, and inheritance just to mention a few (Opoku, 1997, Asante, 2002).

The Akan rural and political organisation is based on matrilineal lineages. The Akan strongly believe that a man is strongly related to his mother's brother ('wofa') but only weakly related to his father's brother (Opoku, 1997, p. xv). Consequently, the uncle-nephew relationships assume an overriding position. The political units are grouped into eight larger groups which are Aduana, Agona, Asona, Bretuo, Ekuona and Oyoko. The chieftaincy system among the Akan, especially the Asante is a thriving institution. The Asante Chief "Otumfuo" is a deity and is revered as such. In this capacity as a deity does not speak directly to his subjects. He uses the services of a linguist. A linguist is one who is well skilled in the art of speech delivery. This art has as a significant part the good use of proverbs. Generally, a good use of proverbs in one's speech is an indication of good oration (Opoku,1997).

\subsection{Dagara and Akan Oral Traditions}

Various aspects of Dagara oral tradition include the singing of dirges, playing of the xylophone, playing dalari (small drums) and 'gangai' (big drums) on special occasions and during entertainment, playing wind instruments such as the

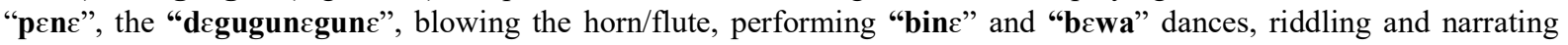
folktales. Women can also exclusively engage in "kaari" and "nuruloba" — types of entertainment based on clapping of hands and certain dances performed by only women. All these activities require some requisite skills and techniques. It is a well-known fact that anybody who wants to learn any of these aspects of Dagara oral arts must acquire a good amount of knowledge and skill and techniques before attempting to perform them in public. For example, "bine" and "bewa" are vigorous dances which do not only require physical energy but also special dexterity and innovation in order to attract public attention (Kyiileyang, 2009, pp. 18-21, 42, 79-84, Kyiileyang, 2016, p. 224).

The Akan like most traditional societies have rich oral traditions. The information is packaged into various forms: stories, songs, sayings. Akan oral traditional stories include folktales, fables, myths, legends, epics; songs include dirges, riddles, work songs, drum language, and sayings such as proverbs (Yankah, 1989, pp.71-81, Opoku, 1997, pp.18-20, Asante, 2002, pp.4-11). Although the information is handed down from generation to generation and anyone can perform any of these oral forms, some aspects are learnt. For example, performers of the drum language and the Adowa dance need special training. This is because hand gestures and body movements during performances have implied meanings. It is important for one to be tutored in these meanings so that a performer will be able to use them appropriately and in the right context. 
Dagara and Akan proverbial expressions are embedded with a lot of images and symbols that are normally taken for granted when people are engaged in various forms of discourse. Many Dagara and Akan understand the superficial meaning of proverbial expressions but not necessarily the figurative representations within these expressions. Most images of contention and violence that are evoked in Dagara and Akan proverbial expressions are terrifying and they deserve a deeper interpretation than what most of their people perceive in discourse. This study is undertaken to prove the fact that Dagara and Akan meta-language is closely bound with their oral literature and traditions. Secondly, Dagara and Akan oratory are rich in various literary features including images and symbols. Additionally, images of contention and violence portray many aspects of Dagara and Akan philosophy. Moreover, Dagara and Akan proverbial expressions expose how verbal expressions are related to discourse. Like most people in Africa, the Dagara and Akan have a rich oral tradition that deserves a thorough investigation. The study on proverbial expressions is one way of enhancing a better understanding of African oral literature especially Dagara and Akan oral literature.

The methodology used for the study was the sampling of proverbs from a variety of Akan and Dagara proverbs gathered by researchers over the years. A textual analysis was done on ten Akan proverbs and ten Dagara proverbs which depict images of contention and violence. The theoretical basis of the paper is the work of two scholars. In their studies on proverbs, Yankah (1989) and Honeck (1997) emphasise Proverb Praxis and the Conceptual Based Theories in the use of proverbs. Though Honeck concurs with Yankah on the cultural context of proverb use, he believes that proverbs can be abstracted from the cultural specifics because the mental structures and processes of Homo Sapiens are explainable on the basis of the same theoretical principles.

\section{Analysis of Dagara Proverbs Depicting Images of Contention and Violence}

\subsection{Analysis of Dagara Proverbs Depicting Images of Contention}

$\begin{array}{cccccc}\text { Proverb No. 1: “Zãzãkyilé yel } & \text { ké } & \text { di } & \text { lang terí zõõr". } \\ \text { bat } & \text { says } & \text { that room } & \text { share has smoke }\end{array}$

(The bat says that sharing residence/a home with someone produces smoke.)

People staying together sometimes develop a poor relationship because of differences in attitude. People who live in the same room, house or environment and share common property often raise complaints against one another. They often complain of inconvenience. The word "dilang" underpins joint ownership of the living room whilst "zuur" depicts complaints, trouble, disputes or disagreements which come as a result of people staying in the same room. We all need to acknowledge that those we are staying with can cause us discomfort from time to time. Such unpleasant or unbearable things are referred to here as "zuur" (smoke). It is a common fact that smoke can cause very unpleasant irritation of the eyes. It is in this way that "Zuur" is a metaphorical image of inconvenience and perturbation. In this case, smoke depicts a vivid image of contention among parties. Certainly, one man's meat is another man's poison. This proverb strongly calls for tolerance for other people's idiosyncrasies. This proverb exhorts us to bear with others in our families and communities. A supportive system in our extended African families is indispensable despite the inconvenience we cause one another.

Proverb No. 2:

$\begin{array}{llllll}\text { Tag-r } & \tilde{\mathbf{i}} & \text { tag-r } & \text { ar- } \varepsilon & \text { nı } & \text { ymãn. } \\ \text { pull-Prog } & \text { 1SG Pron } & \text { pull-Prog } & \text { tear-Prog } & \text { Eph. Calabash }\end{array}$

(Pulling from opposite directions causes the breaking of the calabash.)

This proverb depicts some images of contention and violence. It exposes two or more aggressive parties that do not relent in their violence and arrogance. This can lead to serious problems in society and aggravate an already bad situation. The proverb targets people taking entrenched positions on an issue which can never yield any solution to a problem. The best context one can apply this proverb is in a situation of arbitration; a terrible situation which reaches a deadlock between contending factions. The images of contention and violence are both depicted in the words 'tagr' (pulling with aggression) 'are' (breaking).

Proverb No. 3:

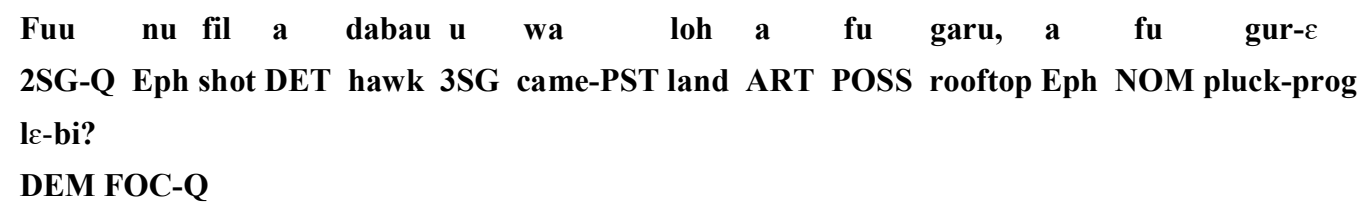

(Were you the one who shot the hawk to land on your rooftop for you to remove the feathers like that?)

There are some people who like to meddle in other people's affairs unnecessarily even when they are not invited. This creates intrusion in people's private affairs. This proverb is a warning against gossips and rumour-mongers as well as 
people who cause unnecessary interference. Somebody affected by the activities of such evildoers can retort by the utterance of this proverb to register anger and dissatisfaction. 'Fil'(shoot/shot) denotes violence whilst 'gure' (plucking the feathers) connotes contention and interference. The proverb can be applied in a situation of somebody poking his nose into other people's affairs thereby creating unnecessary tension and confusion. This can lead to a further dispute between contending parties. 'Dabau' (hawk) is a metaphorical image which depicts the fruit of hard-earned success and nobody should deprive anyone of enjoying this success. The word 'Fil' (shoot) refers to how the success was obtained. Certainly, it was by dint of hard work. The word 'garu' (roof-top of a traditional house of the Dagara people) signifies the temptation and the insinuating implications it has. The act of intrusion is described as 'gure' (plucking out the feathers). The word actually depicts the idea of poking one's nose into other people's affairs uninvited.

In Bedekuru's (2000) collection of Dagara proverbs depicting morality, there are several interesting incidents revealed about issues of contention.

The first one is Proverb No.4:

$\begin{array}{llll}\text { Zentaa } & \text { nyie na } & \text { kab-r } & \text { vuu-mi. } \\ \text { Rivalry-POSS } & \text { yam Eph } & \text { burn-prog } & \text { fire FOC }\end{array}$

(The yam of people who claim the same equality gets burnt in the fire.)

It is similar to Proverb No. 199 in Kyiileyang's collection (2009) which has just been explained. The act of roasting yam is treated with care otherwise, it can easily get burnt in the fire. Two contentious people who have agreed to roast yam must endeavour to check it in turns to ensure it does not get burnt. When there is any disagreement and both of them pass the buck, the yam will eventually get destroyed in the fire. Arrogance, pride and too much equality can mar many things in human endeavours. The word 'zentaa' (bitter rivalry) underscores the image of arrogance and too much equality claimed by rival individuals or factions. The main message of this proverb is humility and lowliness in life.

Proverb No. 5

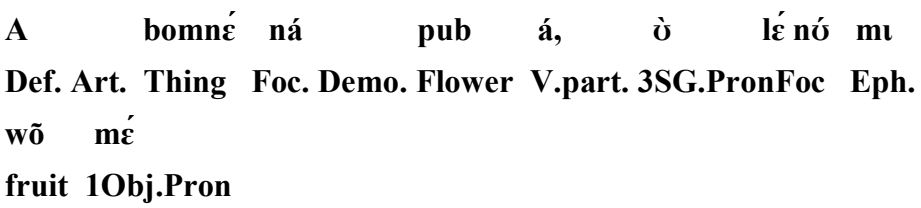

(What has flowered you is the same thing that has fruited me).

A tree normally flowers before it bears fruit and the fruits are more mature than the flowers. Anyone who uses such a proverb to address another is highly contentious in behaviour. Therefore, to use this proverb on somebody means that you want to prove to be more stubborn than the way the person thinks he is. This is a highly contentious proverb often traded between disputing people who are insulting each other in rapid turns. The juxtaposition of flowering and fruiting, in this case, points out the significance of both images to the understanding of the proverb in the right context. An elder is likely to use this proverb against an arrogant youth. However, a highly contentious youth who wants to challenge a respectable elder on a particular issue on which he (youth) claims to have adequate knowledge, can equally use this proverb to demonstrate sheer arrogance.

\section{2 Analysis of Dagara Proverbs Depicting Images of Violence}

There are a lot of proverbs depicting situations of violence in life. In Kyiileyang's (2009) collection, there are several interesting proverbs which depict images of violence. Let us examine the following proverbs:

Proverb No. 6

Waab jme parpar ní waab kó-b.

Snake beat ideophone Eph. Snake kill-Nom.suffix.

(The violent and persistent beating of a snake is the best way to kill it.)

The proverb reminds us of 'A stitch in time saves nine'. This proverb emphasises the fact that it is always advantageous to hurry up and accomplish a task before it is too late. An observer can advise somebody to hurry up with certain plans he has to undertake before time runs out. The significance of this proverb lies in the reiteration of pertinent human endeavours. The image of hurrying up can be delineated in the term 'waab mwe parpar' (violent and persistent beating of a snake). The term "mwe parpar" portrays a violent image of ruthlessness. "Parpar" is an ideophone emphasising the ruthless and the best way to kill a snake which is an image of danger and poison. This actually refers to the quick accomplishment of a task which deserves urgent attention. Elders are likely to advise the youth about unnecessary delays in accomplishing certain things in life such as marrying in good time to live a disciplined and a settled lifestyle. Ageing is one of the crucial factors in marriage relations. Similarly, somebody could offer advice to another on a 
business opportunity which should not be allowed to slip by through the utterance of this proverb. This proverb can be used in a similar context like Proverb No. 7 which talks about the violent killing of a dog.

Proverb No. 7

Baa gburgbur ni baa kú-b .

Dog Ideophone Eph dog kill-Nom.suffix

(A violent and smart tactics adopted is the best way to slaughter a dog).

This proverb means that hurrying up to accomplish one's projects in good time is the best way to attain success in life. This proverb applies in the context of people who are very smart in attitude. The idea of being impetuous does not count in such a situation. The terms 'gburgbur' (violent treatment) and 'kub' (slaughtering) clearly delineate two images of violence: first in the handling of the dog about to be slaughtered and secondly in the killing of the dog itself. The contextual application of this proverb is similar to Proverb No. 6 which deals with the violent killing of a snake.

Proverb No. 8

Kuospiir nyie, kuoวpiir mi wa wob.

Flood-water-prog yam flood-water Eph come-COP collect

(Yam sown on the waterway is often destroyed by floods which pass the same course.)

Generally, floods are violent and destructive as they can cause a lot of havoc on the way. A prudent farmer will not sow seeds on the waterway but an inexperienced or stubborn one will do so and pay for the consequences. It is better to avoid trouble when one foresees it coming. It is better to have foresight than to wait until you are overwhelmed by what could have been avoided. Those who use the sword will die by the sword. Violence begets violence. If you cheat people in life and eventually you also get cheated, then it becomes justifiable to apply the law of retribution. All these are ways of explaining this proverb. The image of violence recurs in the terms Kuospiir nyie ('flood-water yam' i.e. yam planted in the waterway) and kuospiir mi wa wob (floods carry away that yam i.e. destruction of the yam by the violent floods). Nobody pities trouble makers particularly when they get the deserving reward for their troublesome attitude.

Proverb No. 9

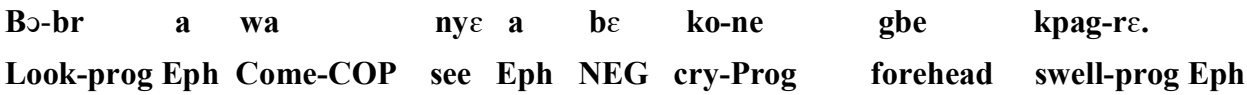

(One does not cry over a swollen forehead when one deliberately looks for trouble).

This proverb is easy to understand. It exposes the fact that the one who looks for trouble should not complain when he finally gets a swollen forehead. This proverb is used to reprimand children who are foolhardy and stubborn. However, it can also be used to admonish adults who are equally troublesome. The term 'gbe kpagr' (swollen forehead) depicts the image of violence vividly.

Proverb No. 10

Dang bang ni don be dang ter tam ka-ba $\quad \varepsilon$.

Earlier-ADV know ACC hatred-NOM NEG Earlier-ADV have bow break-PRF Eph

(Take precaution against an old enemy by rehabilitating the bow).

The English proverb equivalent is 'Forewarned is forearmed'. Among the Dagara, every responsible man particularly those with families must be ready with his bow and arrow in self-defense. It is not good to be taken unawares. However, those who are irresponsible have broken bows exposing their weakness and vulnerability to sudden dangers. 'Don' means enmity and 'tam' refers to bow. Both images reveal symbols of violence. An irresponsible person who fails in his duties or takes serious matters for granted can easily be admonished through the utterance of this proverb.

6. Analysis of Akan Proverbs Depicting Images of Contention and Violence

6.1 Analysis of Akan Proverbs Depicting Images of Contention

Proverb No. 11:

Funtum-fu-na-fuDenkyem-fu-na-fu.

Funtum-stomach-CONJ-stomach Crocodile-stomach-CONJ-stomach

'Siamese crocodiles with a common stomach but struggle for food when eating.'

Crocodiles are very long and big reptiles that inhabit water bodies in temperate regions. The Siamese crocodiles have two upper body parts and two lower sections, an indication that they are two individuals. The issue here is their 
conjoined mid-section. This is the section where food is stored to nourish them. This refers to the proverbial two people with one stomach but struggle for food when eating. The need to taste the food sometimes makes them forget that the stomach is the same. The main concept of this proverb delineates the fact that if the two contenders recognise that the food is entering the same stomach, they will realise that the contention is unnecessary and superfluous. In other words, for one particular group of people in a society, the good things that come to them belong to everybody. There is no need struggling for items that ultimately belong to all. This proverb signifies unity in diversity. This proverb exemplifies the dire need for tolerance in society. If the Siamese crocodile fights over food it is harmful to their survival. Therefore, peace, tranquillity and unity must exist between people. Even as we seek a particular goal in diverse ways we should stay united and peaceful.

\section{Proverb No. 12:}

Twe ma me-ntwena $\varepsilon$-ma-a betwani koraa boe.

Pull CONJ 1SG-pull FOC 3SG-cause-PST palmwine tapper's calabash break-PST

'Pull as I also pull at the same time breaks the palm wine tapper's calabash.'

In the Ghanaian context, the calabash is a pod-like fruit of a tree. For utility purposes, the pod is cut into two and scooped and used in some instances as a bowl in the kitchen. On other occasions, it is used as a vessel of honour as the gods are served their drinks from it. It is used for libation. It has cultural value. In nature, it is a fragile and brittle object that will break when held tight by opposing and contending parties. The calabash here symbolises personalities and things like love and peace. The calabash is a concrete but delicate image of violence. When these things are abused and overstretched, they suffer devastating consequences just as a calabash breaks when held tight by aggressive, contending parties. Therefore, we must endeavour to love one another and stay peaceful. The object of contention is greater symbolically than the contenders. The calabash is fragile and weaker in nature and therefore must be cherished and handled with care. If two individuals decide not to value peace, then the result will be destruction. The word "pull" in the proverb depicts force and resistance. When an aggressive force is exerted on the calabash, it will obviously get destroyed because of its fragile nature. In other words, if two people are in violent disagreement (be they friends, siblings, families) peaceful relationships are destroyed as chaos and violence ensue. When a party refuses to relent, the "peace" that they enjoy will be shattered.

Proverb No. 13:

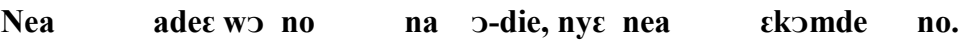

COMPL thing COP 3SG CM 3SG-eat NEG COMPL hunger COP 3SG

'It is the one who owns the thing who uses it, not the one who yearns for it.'

The word adee refers to something of worth such as gold and land. It also could be narrowed down to any item such as food. It is the legitimate owner of a thing who deserves to enjoy. The fact that one is hungry, does not give one the right to claim any food unless one owns the food. This proverb means the owner of a property is the right person to use it. In other words, ownership of something is determined by the rightful owner, not the one who desires to use it or can use it. Any attempt by anyone other than the owner can result in contention or even violence. It is just fair that the set system of ownership is adhered to in order to make sure that peace and tranquillity prevail in society.

Proverb No. 14:

Jkomfo bone se kurom-moa, J- te-mu bi.

priest bad say town PLU-destroy CM 3SG-sit-LOC also

'If a bad fetish (traditional) priest wishes for the doom of a nation, he is part of it.'

The traditional priest among the Akans is regarded as a god and like all deities, the need for a priest is indispensable. The priest is the intermediary between the people and the deity they serve. If a fetish priest seeks damnation for the people he serves, and if the gods visit any misfortune on society, he will equally suffer from the said doom. This proverb refers to the hypocrite who always wishes for the failure or downfall of the community in which that person lives forgetting that when doom comes, he/she too will be damned together with the others. Literally, the proverb underscores the fact that if one prays for a disease outbreak in a society or a particular community, he/she shouldn't forget that he too can contract that same disease.

In contemporary times, this proverb can be quoted for a political figure or group calling for violence and war during the times of elections particularly when that person with their party loses the election. When war breaks out, he and some immediate members may be able to escape the impending destruction but someone close may suffer. The country he wanted to rule will be destroyed and he may end up a refugee in another land. In essence, we should seek the well-being of the land in which we live for our well-being is linked with that of the entire society. No man is an island. 


\author{
Proverb No. 15: \\ Ke-ka-kyerebo kuro. \\ Say-say-show break town \\ 'Hearsay causes the collapse of a town.'
}

The proverb is conveying a message that establishing something on just hearsay from others can really endanger one's aspirations and hopes in life. In addition, the cause of instability of a nation is based on persons involved in rumourmongering, backbiting and mere hearsay.

6.2 Analysis of Akan Proverbial Expressions Depicting Images of Violence

Proverb No. 16:

\begin{tabular}{|c|c|c|c|}
\hline $\begin{array}{l}\text { Wo-de } \\
\text { 2SG-use }\end{array}$ & $\begin{array}{l}\text { kokurobetie } \\
\text { thumb }\end{array}$ & $\begin{array}{l}\text { kJ ayie ayc-de sotorogya } \\
\text { go funeral CM 3PL-use slap }\end{array}$ & $\begin{array}{l}\text { wo kwan. } \\
\text { leave } 2 \text { SG way }\end{array}$ \\
\hline
\end{tabular}

The shortest and thickest finger at the side of the hand is the thumb. The thumb is such a vital part of the human anatomy that one cannot tie a knot without the thumb. Its loss creates a measure of imbalance in the individual's life. In everyday social interaction, the lifting of the thumb communicates nonverbally with different meanings. The people in a particular social setting understand what is being communicated. It is on record that in ancient Greece in the era of the gladiators, thumbs-up was a ticket to live while the opposite was true for those sentenced who get a thumbs-down.

The Ghanaian context is different. Among some social groups in Ghana, the traditional Akan people inclusive, raising the thumb is a sign of arrogance and in some instances, insulting. A slap ('sotors') is a symbol for any number of violent reactions that may result from a rude attitude of somebody at an august event. A funeral in most societies is a celebration of the life of the departed. It is believed among the Akan that, especially if the dead person lived a good and commendable life, he or she will become an ancestor in the next life. An ancestor obtains a deified status and becomes a medium between the living, God and the gods. Therefore, the dead deserve all respect.

It is in this light that if a mourner goes to a funeral with an arrogant attitude or with insults, he will be shown the door exemplified here by ('sotor`') a slap. This proverb emphasises the fact that we should be courteous towards one another. A funeral is a solemn occasion; a serious event and no matter the amount of provocation, it is expedient that mourners exercise much restraint. Any untoward attitude, especially towards those bereaved, would result in a reciprocal hostile reception. The image of violence resides in the word 'sotoro' (slap). A slap is obviously a violent reaction to an unwelcome attitude. But a slap does not just happen in the void; provocation from one party is the triggering act.

Proverb No. 17:

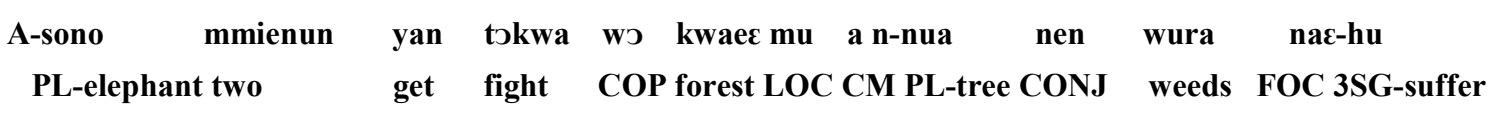

amane.

'When two elephants engage in a fight in the forest, it is the trees and bushes around that suffer.'

The elephant is one of the biggest animals in the forest. Very few animals can stand up against its colossal strength. A physical fight is the use of violence to overpower an opponent. In the case of animals, this may involve kicking, biting and hitting. When the need arises, they can be very destructive in their wake. It is an obvious fact that when two elephants fight, the trees and bushes there suffer most. Forest trees and bushes are suitable metaphorical images to the understanding of the proverb. The image of contention here lies between the two elephants ('Asonommienu'). The elephants in this instance represent two people of high social standing with subjects or subordinates serving them and depending on them. The elephant is representative of people such as chiefs, politicians and even parents among others. An example of a contentious situation is when there is contention for the occupation of a stool. Among most Akan tribes, the stool does not belong to one branch of the family line alone. Contestants may come from different branches of the family lineage. During these contests, the individual contestants have to rally for support among the king-making team. If the issues are not properly handled, things can degenerate into a feud. Now if two such individuals fight, it is the subjects who suffer. The royal family can also disintegrate. Again, in a marriage situation, when there are conflicts and contentions, it is the children who suffer most. The children and royal family are exemplified by 'n-nuanenwuranachu' i.e. the bushes and trees.

Proverb No. 18:

Wo-boro Jbaa-were-fos awo-kontokwa-prenu.
2SG-beat female-marry-PL CM 2SG-fight fight-two

'If you beat a married woman, you engage yourself in a second fight.' 
Marriage, an institution as old as man, is respected in most, if not all societies. People's status in society changes the moment they get married. They are considered to have become more responsible. This proverb leans more towards violence against women. It is implied, by the proverb, that the woman is the weaker of the two persons involved in the dispute, hence the word beat and not fight. A married woman is under the authority of her husband and if any other person beats her, he or she must be ready for a second fight this time round, with her husband. This proverb teaches caution and patience in dealing with people irrespective of how much we are provoked, because you may not know your contender's true background. She may have the support and backing of some influential persons and the situation may lead to more violence and prolonged disputes. The terms 'Wo-boro כbaa-were-for' and 'ntokwa-prenu' outline the image of physical violence depicted by the utterance of this proverb.

Proverb No. 19:

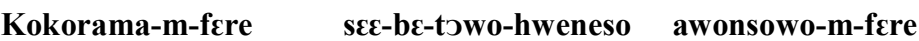

Cancer PRF-NEG-shy CM 3SG-FUT-lie 2SG-nose LOC CM 2SG also 2SG-NEG-shy

se wo-deasaawa be-tare so.

\section{2SG-use cotton FUT-lie LOC}

'If cancer did not feel shy to infect your nose, you also do not feel shy to cover it with cotton wool.'

The sixth edition of Oxford Advanced Learner's Dictionary (2000, p. 170) defines cancer, as a "serious disease where growth cells form in the body and kill normal cells". If this debilitating disease affects one's nose, one should not be embarrassed when one has to apply medication to one's nose. Cancer in this proverb represents any situation afflicting an individual that is embarrassing, denigrating or even catastrophic to a large extent. The nose is a visible part of the face, but when the need arises, its visibility should not stop the patient from doing what is necessary. It is the ultimate result that matters and that is the gist of this proverb. If a person has the effrontery to misbehave towards another in public, it is justifiable for the offended party to pay the offender in a similar fashion; just a situation of tit for tat. The law of retribution is implied in this proverb. The bone of contention here lies between the 'kokoram' and the affected person. Respect and tolerance towards one another will avert any violence and would promote peaceful co-existence. Any issue that can be dealt with in secret and with regard for the value of peace is the better option.

Proverb No. 20:

Segyaesaaa-n-nyaesaa a, gyae ma $\varepsilon$-n-kanso n-nyae

COMP stop FOC COMPL-NEG-stop FOC CM stop give 3SG-NEG-leave also NEG-stopma $\varepsilon$-n-ka. give 3SG-NEG-leave

'If stop doing that does not stop doing it, leave it to rest will also not leave it to rest.'

"Gyae" is a command which emphasises stop. When one is asked to stop an act, especially one that is not going down well with those around, and one refuses, the offended party will also not let things rest. In turn, it could also mean that if a person is stubborn, unforgiving and will not let go offence when possible, people will also not forgive him/her when that person offends them. Such attitude can prolong situations of conflict. The good book says we should forgive others as the Father in heaven has forgiven us our transgressions. (Matthew 6:12) Therefore, we should learn how to let things go so that love and peace will grow among us.

Proverb No. 21.

Wo-tianyanyankyercya-yaa-yaa, $\varepsilon$-kawoya-yaa-ya.

2SG-step scorpion pain-pain-pain COP 3SG-bite 2SG pain-pain-pain

'If you step on the scorpion mercilessly, it also bites you in return mercilessly.'

The scorpion in most cases is venomous. When it feels threatened it fights back by biting. Oppression breeds rebellion and violence begets violence. When people are treated badly, they cultivate the same attitude. They then retaliate with a greater measure with which they were treated. Such antagonism and violence could occur among families or groups in a society. If members of a society do not treat one another fairly, with respect and tolerance, there will be trouble that could be potentially cyclical. The image of violence is symbolised by the terms "wotianyanyankyero" and "okawo."

\section{Findings of the Study}

Akan and Dagara proverbs like most other Ghanaian proverbs have several stylistic qualities. They are pithy and terse in nature. e.g.Dagara Prov. No. 1 --“Zãzãkyilé yelké dilang terí zõõr". Akan Prov. No. 11 --"Funtum funa fu Denkyem funafu". Some of the proverbs selected for this study portray similar linguistic features such as repetition of words, phrases and ideas.e.g.Dagara Prov. No. 2 "Tagr ĩ tagr are nı ymãn”. Akan Prov. No. 11"Funtum funafu Denkyem funafu". Akan Prov. No. 12 "Twe ma mentwenacma a betwanikoraabjec". The effectiveness of repeated terms such as "tagr" (pull), "twe" (pull) and "funafu" (stomach) underscores and reiterates a certain rhythmic pattern in the utterance of these proverbs. The tone of the speaker of these proverbs exhibits some force and portrays the urgency of the subject matter referred to in the contextual use of the proverb. Other Dagara proverbs which portray vivid images of contention and violence are Proverb No. 3 in which the words "fil"(shoot/shot) and "gure"(plucking out features) denote 
unnecessary intrusion in other people's private affairs uninvited. "Gure" refers to a direct cause of contention. Also, in Proverb No. 4, the word "zentaa" emphasises rivalry and equation (of wrong) as negative practices in our daily lives. A similar idea on arrogance is seen in "pub" and "wõ" in Proverb No. 5 where there is a vivid juxtaposition of the two words. "Wõ" is a direct result of "pub". Culturally, among the Dagara, the elder is perceived as always right no matter the cause of errant behaviour.

In comparison with previous studies conducted by Yankah (1989), Opoku (1997), Bangnikon (1999) and Asante (2002) one can say that Akan and Dagara discourse situations are replete with proverbial expressions depicting images of contention and violence. Yankah (1989, pp. 97-98) cites three proverbs emanating from a song performed by "Sparrows Band" which reflect contentious issues or violence. The first says, (among other things) "If the beast will not bite, it doesn't bare its teeth". Secondly, the musicians added, "The hen's elegant dance never pleases the hawk". Yankah stresses that these two proverbs emphasise tension between a friend and a foe depicting two images of confrontation. In fact, a solution to the enmity is sought in a third proverb, "A sharp twig threatening the eye is uprooted not clipped". In other words, the trail of an avowed enemy is avoided not trodden. Such proverbs uttered orally can also be represented visually through art, a fact corroborated by Opoku (1997, p. xviii), "the entire world of the Akan is reflected in their proverbs". Some conflicts could be resolved through unusual dress style or even behaviour. Among the Akan, many proverbs are well represented through funeral cloths known as "adinkra". They appear on objects like gold weights, spokesman staff, umbrella tops which could portray pictures of the crab, elephant or snake.

In divorce cases, Yankah (1989, p.195) cites two proverbs to vividly portray the consequences of troubled marriages. "The wretched sponge is picked up in needy times" is cited by a mother to a son who divorced his first wife and realized that the second wife was not better than the first one. A man who divorced his wife three times and returned in remorse was told, "The enigmatic hollow bone: when you lick it, your lips hurt; when you leave it, your eyes trail it". In this paradoxical expression, the woman accepted the erring husband in delight and agony. Her sarcastic words revealed that she had some kind of irresistible charm which kept the man coming back to her. Opoku (1997, pp. 26-27) cites fourteen proverbs on marriage and five of them are based on contentious marital issues. These are Proverb Nos. 114, 117, 121, 122 and 124. Proverb No. 122 delineates an interesting hyperbole based on the fact that a man with a thousand wives has a thousand tongues. Such tongues are bound to be persistently wagging ones.

Bangnikon's (1999) proverbs were collected and arranged in alphabetical order. In fact, he had an ambitious project of collecting most Dagara proverbs ranging from A-Z. He only got to 'B' before he passed on. Every proverb is stated in the Dagara language followed by a literal translation, explanation and moral teaching behind it. Sometimes, the writer presents more than one moral teaching to a proverb citing examples from other languages particularly English. Asante (2002, pp. 30, 46, 50, 52, 63, 69 and 71) cites Proverb Nos. 5 (iii), 13, 17, 18, 21, 24 (i) and 26 (i) to depict various situations of contention and violence especially Proverb No. 18 which talks about the dreaded mythical creature, Sasabonsam in Akan mythology. It can cause great confusion and destruction for humans. Yankah and Asante both emphasise the significance of Akan proverbs in diverse discourse situations. Yankah (1989, p. 251) says, "particular discourse themes that attract proverbs would differ from culture to culture, but they range from ordinary conversation to debate, argument and other situations". This is corroborated by Asante (2002, p. 2), Akan proverbs run "through formal and informal discussions, private conversations, bitter arguments and petty quarrels ceremonial orations, public lectures and story-telling". These researchers have delineated various situations in proverbs which portray images of contention or violence. Similarities in metaphorical, paradoxical, personified and ironical images are drawn from the numerous proverbs that they cited. For instance, the mythical character Sasabonsam is similar to the Dagara Vigdanyiim, a mythical, weird but dreaded anthropomorphic figure commonly cited in Dagara proverbial expressions and folktale narration. However, the differences one observes in all these collections and interpretations lie in the cultural contexts in which the various proverbs are applied.

The study of the proverbs done so far reveals the metaphorical image as the most dominant figurative quality connected with Dagara and Akan proverbial expressions. This is exemplified by the following words: "zõũr" (smoke) an image depicting the idea of being delicate and vulnerable. "Gbe kpagr" (swollen forehead) an image of a foolhardy and stubborn person. In fact, "Kone gbe kpagr" (crying over a swollen forehead) depicts the disastrous effects of violence visited upon a stubborn person. "Funtum" and "Denkyem" refer to two separate people from the same family, party, union or association. These words exemplify metaphorical images of parochial interest and unnecessary tension. The word "sotoro" is another image depicting violence that an arrogant person experiences as a result of his stubborn and insulting behaviour towards people who have suffered a misfortune.

The aesthetic qualities embedded in these proverbs equally point out the significance of Dagara and Akan cultural values in the context in which the proverbs are used. e.g. Decorum is cherished greatly during funerals as shown in Akan No.16. The Akan and Dagara societies are characterised by the spirit of unity, solidarity and communalism. Any social deviant is considered disrespectful and arrogant and in some cases an outcast. Akan Proverb No. 11 underscores the need to strive for true democracy and oneness (unity) irrespective of cultural differences. The repetition of the word "funafu" underlines common interest which must be sustained in the same cultural environment. The calabash is also a symbol of unity, wholeness, solidarity and security. It is used among the Akan and Dagara in the presentation of libation and offering of sacrifices. e.g. It is used in serving 'pito' and palm-wine in traditional homes.

Ideophones (with rhythmic qualities) are equally significant in some of the proverbs that were examined in the study. In Dagara Proverb Nos. 6 and 7, the words "parpar" and "gburgbur" are ideophones emphasising the ruthless and the best way to kill a snake and a dog respectively. Whilst the snake is an image of danger and poison dog represents a tough 
and dangerous animal whose slaughtering requires a particular rough skill and tact from the butcher. It is in this way that the terms "mwe parpar" and "gburgbur" portray violent images of ruthlessness. Other notable linguistic features from the study are repetition of words, phrases and ideas and synecdoche e.g: "funafu"

Dagara Prov. No. 2 "Tagr i tagr arع ymãn”.

Akan Prov. No. 2 "Twemamentwenacma a betwanikoraabjes".

The effectiveness of repeated terms such as "tagr" (pull), "twe" (pull) reiterates a rhythmic pattern in the utterance of these proverbs. The tone of speaker exhibits force and urgency of the subject matter referred to in the contextual use of the proverb.

\section{Conclusion of the Study}

Many structural features have emerged from the study of African proverbs. Some of these are diction and syntax. Most proverbs have an unusual word order. In terms of stylistic devices, there is a frequent use of ellipsis, alliteration, assonance and internal rhymes. Hidden meanings of proverbs are conveyed through various figures of speech. For instance, Nigerian proverbs are brief, sententious, metaphorical, paradoxical and full of similes (Pachocinski, 1996, p. 7). These features are equally found in Akan and Dagara proverbs. The physical and psychological equilibrium of both the hearer and the speaker are essential to the total comprehension of proverbs. Another important linguistic feature is symbolism because it helps people to understand proverbs well enough. What actually counts a lot is the maturity of these linguistic symbols. Many proverbs express symbolic values in various ways; they also employ the modes of comparison and contrast so as to make the language much more effective. (Pachocinski, 1996, p. 5) Another notable thing about proverbs is the form of proverbs. Generally, proverbs appeal strongly to the senses because of the use of concrete objects to represent abstract ideas. Proverbs used with some positive and corrective meaning and intention are easily understood. Those that are complicated by the use of symbols are often interpreted by elders of the society.

One major aspect of the interaction between the oral and literary traditions in the African novel is the phenomenon of the story-within-the-story; that is, the narrative proverb. Most novelists endeavour to portray many values through myths, folktales, fairytales, fables, anecdotes, ballads and song tales. These embedded stories are referred to as narrative proverbs in oral speech and in creative literature (Achebe, 1958, pp. 67-70, Obiechina, 1993, p.124). The African novel, in general, abounds in the use of proverbs and this fact has been acknowledged by critics in essays and monographs. The story itself is a primary form of the oral tradition, primary as a mode of conveying cultural, experience and values and as a means of transmitting knowledge, wisdom, feelings and attitudes in oral societies. In fact, the story embedded within the narrative provides, a vivid example of a neat combination of orality and literacy which calls for serious attention. Obiechina points out categorically that narrative proverbs are autonomous stories that appear in different genres and narrative registers within different structural linguistic plans and are embedded inside larger, more inclusive narratives. They function as images, metaphors and symbols and advance the meanings and formal qualities of the narratives in which they occur (Obiechina, 1993, pp. 124-125).

The style and structure of African proverbs are typically poetic. Most African proverbs express universal truth and this is normally conveyed literally through direct comparison (simile) or frequently through an indirect comparison (metaphor). The figurative nature of proverbs is indisputable. The literal forms of proverbs often contain some allusion or a picturesque form of speech. Additionally, some express the poetic quality of rhythm as in the following: "The dying of a heart is a thing unshared"; "If the chief speaks, the people make silent their ears" and "He devoured the Kaffir-beer and it devoured him." These are typically South African Proverbs. For example, the Hausa-speaking people say that "a chief is like a dust-heap where everyone comes with his rubbish and deposits it" (Finnegan, 1970, pp. 395396 cited in Kyiileyang, 2009, pp.67-69). Just as rubbish is unwanted, most of the complaints too are unpleasant to hear.

Proverbs are not only poetic and figurative in nature. They are also pithy as well. This means that few words are often used to convey their message with terseness and thrust. The terse nature of proverbs can be seen in Bantu, Swahili, Zulu, Xhosa, Thonga, Nyansa, Karanga and Lamba proverbs. The pithiness of proverbs can be seen in the kind of imagery, metaphors and symbolism that are embedded in proverbs. Certainly, both poetry and proverbs are economical in words and rich in meaning (Finnegan, 1970, pp. 399-400).

Nowadays, the fixity of proverbs is controversial. Contrary to past definitions, the form and meaning of the proverb are not fixed. They move together with usage. Proverbs have multiple meanings. According to Yankah, (1989, p. 153), "the proverb does not stay at one place, it flies". Dalfovo emphasises that the diversity of Lugbara culture is reflected in its language. These linguistic differences are recognised in the variants that exist in several Lugbara proverbs. Therefore, the fixity of a Lugbara proverb is found in its main pattern. However, practically, when a proverb is used listeners can easily respond in one of its variants. (Dalfovo, 1994, p. 10) Thus, Yankah (1989, p. 28) refers to "an analytical dichotomy between the proverb concept and proverb in context." The problem of fixity is even compounded by the contradictory nature of proverbs as some advocate.

Finally, it must be reiterated that Dagara and Akan meta-language is closely bound with their oral literature and traditions. Examples are the bagr festival, historical events in naming people, Dagara and Akan orature are rich in various literary features including a variety of images and symbols. Images of contention and violence portray many aspects of Dagara and Akan philosophy. e.g. death and funeral celebrations. Dagara and Akan proverbial expressions expose how verbal expressions are closely related to many situations of social discourse. 


\section{Acknowledgements}

We thank the authorities of the University of Education, Winneba for their support in our academic research. We express our profound gratitude to the Head of the Department of English Education, Dr. Amma Abrafi Adjei and the Dean of the Faculty of Foreign Languages Education and Communication Studies, Dr. Rebecca Akpanglo-Nartey for their support of our attendance of the 2016 Linguistics Association of Ghana (LAG) Conference in Tamale where we presented a joint paper on Dagara and Akan proverbs. Thanks to Dr. Charlotte Fofo Lomotey who offered useful suggestions to shape this paper. We are equally grateful to Mr. William Gyamfi-Tenkorang for helping us with some data on Akan proverbs used for this study. We also thank Miss Doreen Yegblemenawo Enyonam of the Department of French Education for helping us to translate the Abstract into French. Discussions were also held with some colleague lecturers of the Departments of English Education and Ghanaian Languages from whom we learnt several ideas to guide us in our write-up and proof reading. We thank all of them for their support and encouragement.

\section{References}

Achebe, Ch. (1958). Things Fall Apart. The UK, Heinemann Educational Books Ltd.

Anyidoho, K. (1983). "Oral Poetics and Traditions of Verbal Art in Africa”, Dissertation, Austin: University of Texas.

Asante, E. K.A (2002). Akan Proverbs, Accra: Asempa Publishers.

Bangnikon, L. (1999). A Book of Dagara Proverbs, Wisdom, and Humour. Volume one. Tamale: TICCS Publications

Bedekuru, A. (2000). Exposition of the Dagara Morality as Brought Out in their Proverbs, Unpublished Memoire, Wa: Wa Catholic Press.

Brunvand, J. (ed.). (1996) American Folklore: An Encyclopedia. New York: Garland.

Champion, S. (1938). Racial Proverbs. A Selection of the World's Proverbs Arranged Linguistically. London: George Routledge.

Dalfovo, A.T. (1994). Lugbara Proverbs, Rome: Comboni Missionaries.

Dundes, A. (1975). On the Structure of the Proverb. Proverbium, 25 961-973.

Egonu, I. (1987). “The Nature and Scope of Traditional Folk Literature”, Editions Présence Africaine, 144 (4), 109117.

Elwell-Sutton, L. P. (1954). Persian Proverbs. London: John Murray.

Fergusson, R. (ed.). 1983. The Facts on File Dictionary of Proverbs. New York: Facts on File Publications.

Finnegan, R. (1970). Oral Literature in Africa. Oxford: Clarendon Press.

Finnegan, R.(1992). Oral Traditions and the Verbal Arts. London and New York: Routledge.

Honeck, R. P. (1997). A Proverb in Mind: The Cognitive Science of Proverbial Wit and Wisdom. Mahwah, NJ: Lawrence Erlbaum Associates, Publishers.

Hornby, A. S. (Ed.). (2000). Oxford Advanced Learner's Dictionary of Current English (6th Edition), Oxford: Oxford University Press.

Hulme, F. E. (1968). Proverb Lore, London/Detriot, Elliot Stock, 62. Paternoster Row E.C./Gale Research Company, Book Tower.

Iheanachor, Egonu. (1985). 'The Nature and Scope of Traditional Folk Literature', Research in African Literatures, 139-145.

Kuusi, A. (1972). "Towards an International Type-System of Proverbs,"

Proverbium 19, 698-736.

Kyiileyang, M. (2009). Exposition of Dagara Proverbs of Nandom Traditional Area: Context and Tropes, Unpublished M.Phil. Thesis, University of Cape Coast: Cape Coast: University Press.

Kyiileyang, M. (2016). "Literary Aesthetics in the Narration of Dagara Folktales" In Advances in Language and Literary Studies, Australia, 7 (6):221-236.

Kyoore, P.S. (2009). Folktales of the Dagara of West Africa. Vol 1: Accra: Qolins Publishing.

Lakoff, G., \& Turner, M. (1989) More Than Cool Reason: A Field Guide to Poetic Metaphor. Chicago: University of Chicago Press

McCoy, R. F. (1988). Great Things Happen: Personal Memoir of the First Christian Missionary Among the Dagaabas and Sissalas of Northwest Ghana. Montreal, Missionaries of Africa.

Merwin, W.S. (1973). Asian Figures, New York: Atheneum.

Mieder, W. (1986a). Encyclopedia of World Proverbs. Englewood Cliffs, New Jersey: Prentice-Hall.

Mieder, W. (2004) Proverb: A Handbook, London: Greenwood Press. 
Norrick, N. R. (1985). 'How Proverbs Mean: Semantic Studies in English Proverbs'.Trends in Linguistics Studies and Monographs 27. New York: Mouton Publishers.

O. Gabor, N. "Kozmanda”. (1979). Vilagirodalmi Lexicon Encyclopaedia of the Worlds Literatures, 6, 645.

Obiechina, E. (1993). "Narrative Proverbs in the African Novel”. Research in African Literatures, 24(4),123-140

Opoku, K. A. (1997). Hearing and Keeping Akan Proverbs.Vol. 2. Accra, Asempa Publishers.

Pachocinski, R. (1996). Proverbs in Africa-Human Nature in the Nigerian Oral Tradition.Minnesota, USA: A Professors World Peace Academy Book.

Stevenson, B. (1948). The Home Book of Proverbs, Maxims and Familiar Phrases, NewYork, Macmillan, and Company.

Stone, J. R. (2006). The Routledge Book of World Proverbs, USA, and Canada: Routledge.

Taylor, A. (1995). “The Proverb”. Standard Dictionary of Folklore Mythology and Legend: 902-905. Cited earlier in Taylor, A. (1931). The Proverb. Cambridge, MA: Harvard University Press and The Proverb.(1962). Hartboro: Pennsylvania.

Voo, G. (1989). Igazemberitgzat szol. Kozmondasok a romani ai Magyar folk lorbol A True Man Tells the Truth. Proverbs from the Folklore of Hungarians in Romania, 19.

Whiting, B. (1932). “The Nature of the Proverb”.Harvard Studies and Notes in Philology and Literature, 14, $273-307$. Yankah, K. (1989). The Proverb in the Context of Akan Rhetoric-A Theory of Proverb Praxis. New York, Peter Lang. 